\title{
Perkinsus karlssoni n. sp. (Apicomplexa) in bay scallops Argopecten irradians
}

\author{
S. E. McGladdery ${ }^{1}$, R. J. Cawthorn ${ }^{2}$, B. C. Bradford ${ }^{2}$ \\ ${ }^{1}$ Department of Fisheries and Oceans, Gulf Fisheries Centre, PO Box 5030, Moncton, New Brunswick, Canada E1C $9 B 6$ \\ ${ }^{2}$ Department oi Microbiology \& Pathology, Atlantic Veterinary College, University of Prince Edward Island, 550 University \\ Avenue, Charlottetown, Prince Edward Island, Canada C1A 4P3
}

\begin{abstract}
In May 1989 a previously unidentified apicomplexan parasite was found in broodstock bay scallops Argopecten irradians from the east coast of Canada. Host tissue responses ranged from focal hemocytic encapsulation to the formation of abscesses containing necrotic hemocytes, parasites and ceroid. Bay scallops held for $6 \mathrm{mo}$ in closed-system, artificial seawater at 22 to $24^{\circ} \mathrm{C}$ produced detectable infections much earlier than specimens grown in estuarine waters. Additionally, the lesions in experimentally held bay scallops showed less phagocytosis and encapsulation than those found in fieldsampled bay scallops. Transmission of the parasite appears to be direct, having occurred during the brief exposure of the spat generation to infected broodstock. The parasite was undetectable in bay scallops under 7 to $10 \mathrm{~mm}$ in length (i.e. $<6 \mathrm{mo}$ old) and only appeared in tissue sections after the scallops had been held for $6 \mathrm{wk}$ in warm water. Thioglycollate culture of tissues from infected scallops yielded zoosporangia which stained blue-black with Lugol's iodine. This test is diagnostic for Perkinsus species; however, the concentration of zoosporangia in the bay scallop tissues did not attain the levels found in previously described Perkinsus species. The species herein described is a new species based on both morphological and epidemiological differences from previously described species. The name proposed is Perkinsus karlssoni after John D. Karlsson, who has provided extensive studies of bay scallop reproductive biology as well as parasites. Biflagellate zoospores released from the Lugol-positive zoosporangia when transferred to seawater survived over $6 \mathrm{wk}$ at $4^{\circ} \mathrm{C}$, but were unable to tolerate either full-salinity seawater $(3.3 \%)$ or salinities under $1.4 \%$.
\end{abstract}

\section{INTRODUCTION}

Numerous parasites have been reported from bay scallops Argopecten irradians (Ray 1954, Morrison \& Shum 1982, 1983, Leibovitz et al. 1984a,b, Leibovitz 1989, Karlsson 1990), most of which do not adversely affect their hosts. The only significant cause of mortality is chlamydiosis in hatchery-reared bay scallop spat (Leibovitz 1989), as previously speculated by Morrison \& Shum $(1982,1983)$. The question of whether or not other previously innocuous parasites might assume pathogenic status under artificial rearing conditions arose with the appearance of a previously unidentified apicomplexan parasite in bay scallop broodstock at 2 Canadian east-coast hatcheries.

The bay scallop is a non-indigenous species in Canadian waters (Gutsell 1930, Clarke 1965), which was introduced for aquaculture purposes in the early 1980's. Spawning is restricted to temperature-controlled hatchery facilities and spat are transferred to open water in spring. After one summer of growth the bay scallops reach market size and some are returned to the hatcheries as broodstock to produce spat for the following year. Since the majority of broodstock die shortly after spawning (Gutsell 1930, Sastry 1970), bay scallops are an annual aquaculture crop in Canadian waters.

In May and June 1989, samples of broodstock bay scallops were collected from 2 Maritime shellfish hatcheries and examined histologically for parasites. During these examinations a previously undescribed parasite was found in the digestive gland, mantle, gonads, gills and connective tissue. As bay scallops are a non-indigenous species, and no similar parasite species have been detected, to date, in native bivalves, there was concern with respect to the disease potential of this parasite to native bivalve species, especially American oyster Crassostrea virginica, blue mussel Mytilus edulis, sea scallop Placopecten magellanicus and various clam species. The only similar parasite previously reported from bay scallops was from Rhode 
Island, USA (Karlsson 1990). Although Karlsson did not describe the morphology of the parasite found in bay scallops from Rhode Island, comparison of material from Canada and Rhode Island shows that specimens are histologically identical. Karlsson proposed that the parasite was of 'potential pathogenic significance' because of its location in the gonads and his observation of its occasional occurrence within ova.

Detailed pathology investigations were carried out during the quarantined introduction of the bay scallop and only chlamydia-like and rickettsial infections were noted, as described by Morrison \& Shum $(1982,1983)$. Subsequent examination of histological sections from the original broodstock imported to Canada, however, has revealed the presence of identical lesions. At the time of importation, these were identified as nonspecific 'granulomas' since the hemocyte aggregations completely masked the contents of the lesions.

Initial histological examination of the broodstock in 1989 revealed hemocyte encapsulation similar to that described for a Perkinsus species in Macoma balthica (Farley 1977) and Lugol-positive zoosporangia in thioglycollate culture. This indicated that the parasite had certain characteristics similar to those of the pathogenic Perkinsiidae (Apicomplexa) (Ray 1954), e.g. P. marinus of the American oyster (Mackin et al. 1950), $P$. olseni of the blacklip abalone Haliotis ruber (Lester \& Davis 1981) and P. atlanticus of the clam Ruditapes decussatus (Azevedo 1989). These observations, as well as the report by Ray \& Chandler (1955) of $P$. $(=$ Dermocystidium $)$-like organisms in $100 \%(\mathrm{n}=11)$ Argopectens irradians from Florida, led to the investigation of whether or not this was a Perkinsus species. Experimental holding systems for spat collected from known infected bay scallops were designed to optimize development of this group of parasites (Ray 1954).

\section{MATERIALS AND METHODS}

Initial observations. In May 1989, 40 post-spawning bay scallops were examined for pathogenic agents prior to release of the spat generation for aquaculture in the Gulf of St. Lawrence. Transverse sections $(3 \mathrm{~mm}$ thick) of each scallop were collected, as described in Howard \& Smith (1983), and fixed in Davidson's solution for $24 \mathrm{~h}$ prior to paraffin-infiltration and embedding. Six $\mu \mathrm{m}$ sections were stained with Harris' modified hematoxylin and $0.5 \%$ alcoholic eosin y. Additional slides were prepared from both samples using Gram stain, Acid-Fast stain and Malt Periodic Acid Schiffs (MPAS). Tissue samples from 20 of these scallops were cultured in Fluid Thioglycollate medium

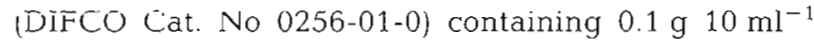
chloramphenicol (Sigma Cat. No C-0378), and nystatin (Sigma Cat. No N-3505), at room temperature (20 to $22^{\circ} \mathrm{C}$ ) for $96 \mathrm{~h}$ prior to staining with $50 \%$ Lugol's Iodine (Ray 1966). A sample of ca 150 spat ( 1 to $2 \mathrm{~mm}$ diameter) was also examined, as described above, after dissolving the shells, post-fixation, in EDTA (Howard \& Smith 1983) for $24 \mathrm{~h}$. Two repeat samples of spat were incubated in Fluid Thioglycollate medium at the Fish Health Unit, Department of Fisheries and Oceans, Scotia-Fundy Region, Halifax, Nova Scotia.

In June 1989, the remaining bay scallop broodstock $(n=6)$ at a second shellfish hatchery were examined using the same techniques as described above. Duplicate samples for light microscopy were fixed in $1 \%$ glutaraldehyde/ $4 \%$ formaldehyde (1G4F) solution (Howard \& Smith 1983).

Development of parasite in spat generation. Since all the infected bay scallops died shortly after spawning, no adult bay scallops were available for further investigation after the June 1989 sample. In August,

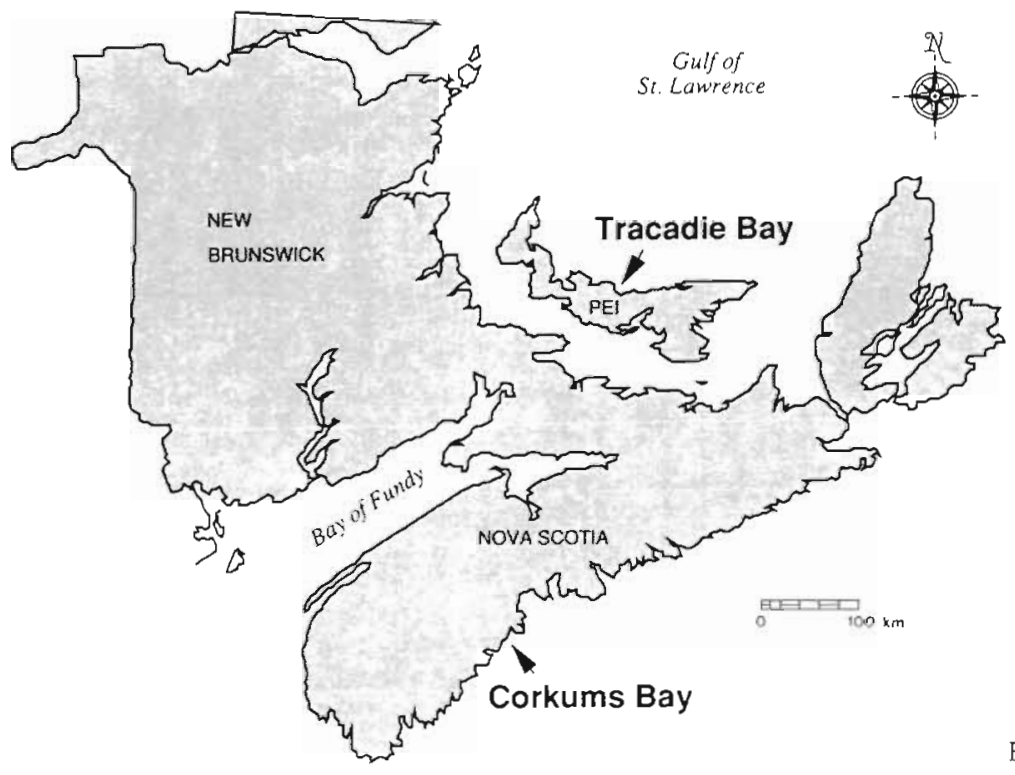

Fig. 1 Location of collection sites in eastern Canada 
therefore, ca 1000 spat were collected directly from hatchery tanks at a Nova Scotia hatchery with known infected broodstock and from a grow-out site on Prince Edward Island (PEI). These spat were placed in 2 tanks fed by a closed-circulation, artificial seawater (Instant Ocean), quarantine system at the Atlantic Veterinary College, Charlottetown, PEI. Water temperatures were maintained at 22 to $25^{\circ} \mathrm{C}$ and the bay scallops monitored for the parasite weekly for the first month and, thereafter, every second week, using histology and thioglycollate culture as described above. They were fed twice daily on carboy cultured algae and SDA (Spray Dried Algae (Tetraselmis), Cell Systems Ltd, Orwell House, Cowley Road, Cambridge CB4 4WY, UK).

Observations of zoosporangia and biflagellate stages in artificial seawater. Tissues which were Lugol-positive following thioglycollate culture were placed in $9 \mathrm{~cm}$ diameter petri dishes containing artificial seawater inoculated with nystatin and kept at room temperature ( 18 to $22^{\circ} \mathrm{C}$ ). These dishes were monitored daily for development of zoosporangia and biflagellate zoospores. Sub-samples from dishes containing the zoospores were placed in a refrigerator at $4^{\circ} \mathrm{C}$, as well as in various salinities of artificial seawater $(0.5,1.4$ and $3.3 \%$ ). The motility of the biflagellates was monitored regulary until there was no resumption of lost motility on return to room temperature and $2.8 \%$ salinity.

Development of parasite under ambient field conditions. Field samples of 100 bay scallops were collected from Corkums Bay, Nova Scotia and Tracadie Bay, PEI (Fig. 1), and examined for parasite development. In addition, samples of 100 American oysters and 100 blue mussel adults were collected from Tracadie Bay and 100 European oysters Ostrea edulis and 100 blue mus- sels were collected from Corkums Bay. These were all examined, using light microscopy and thioglycollate culture, as described for the bay scallop analysis.

\section{RESULTS}

In recognition of the extensive contribution made to knowledge of bay scallop reproduction and parasites by Mr John D. Karlsson, Coastal Fisheries Laboratory, Rhode Island, we are naming this parasite Perkinsus karlssoni.

\section{Description of Perkinsus karlssoni n. sp.}

Measurements given in the following description are taken from 50 specimens each of aplanospores and mother cells found in moribund bay scallops. A total of 50 zoosporangia and 50 zoospore specimens were taken from thioglycollate culture for measurement.

Aplanospores were all measured from $1 \mathrm{G} 4 \mathrm{~F}$-fixed specimens. They were usually spheroid shaped, diameter $6.11 \pm 0.96$ (4.3 to 7.6 ) $\mu \mathrm{m}$ (mean \pm 1 standard deviation with range of measurements in parentheses) (Fig. 2). Wall thickness of individual aplanospores was $0.4 \mu \mathrm{m}$ and the cytoplasm contained acidophilic granules and multiple vacuoles. Multiple fission produces mother cells of 2 to 32 individuals. In some aggregations it was impossible to distinguish one mother cell from another and counts from these are not included, although there may have been individuals with more daughter cells than described above. The diameter of individually distinguishable mother cells was $36.08 \pm$ $20.33(12.96$ to 73.44$) \mu \mathrm{m}$. The nucleus of individual

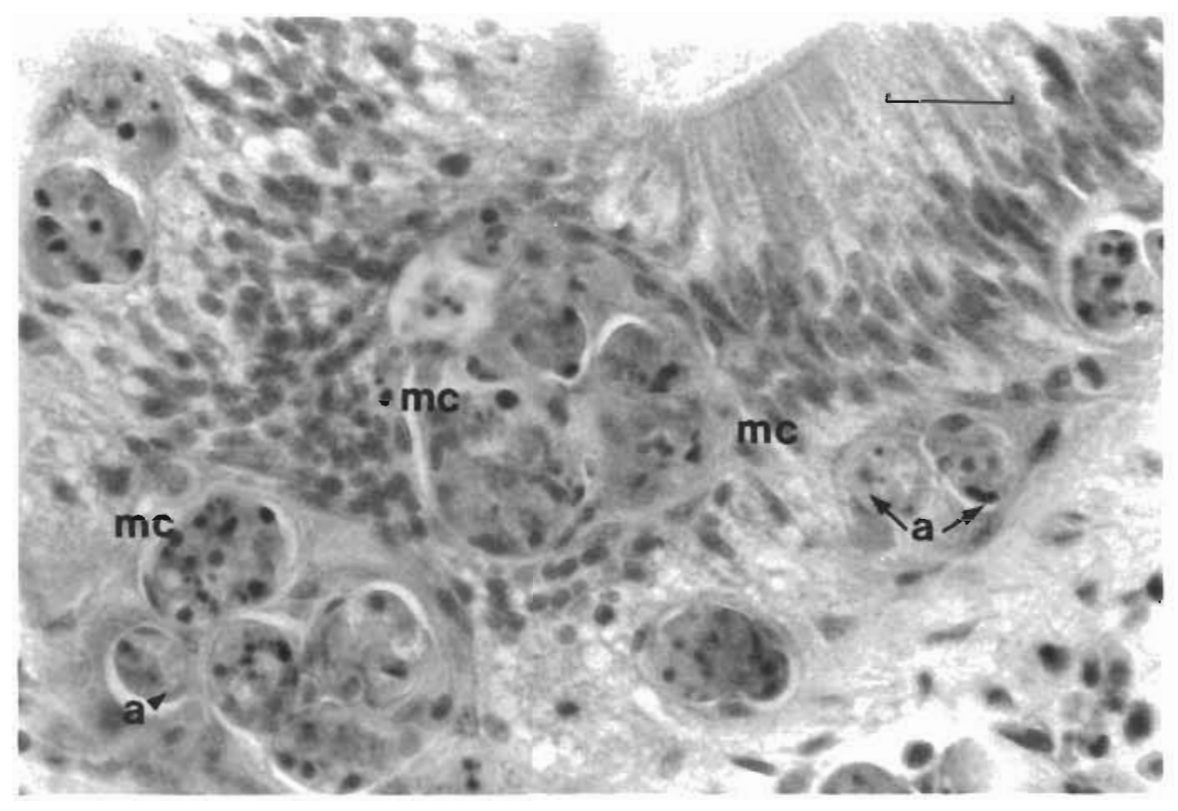

Fig. 2. Perkinsus karlssoni aplanospores (a) and mother cells (mc) amongst the epithelial cells of the intestine. $\left(\mathrm{H} \& \mathrm{E}_{\text {; }}\right.$ bar $\left.=17.5 \mu \mathrm{m}\right)$ 


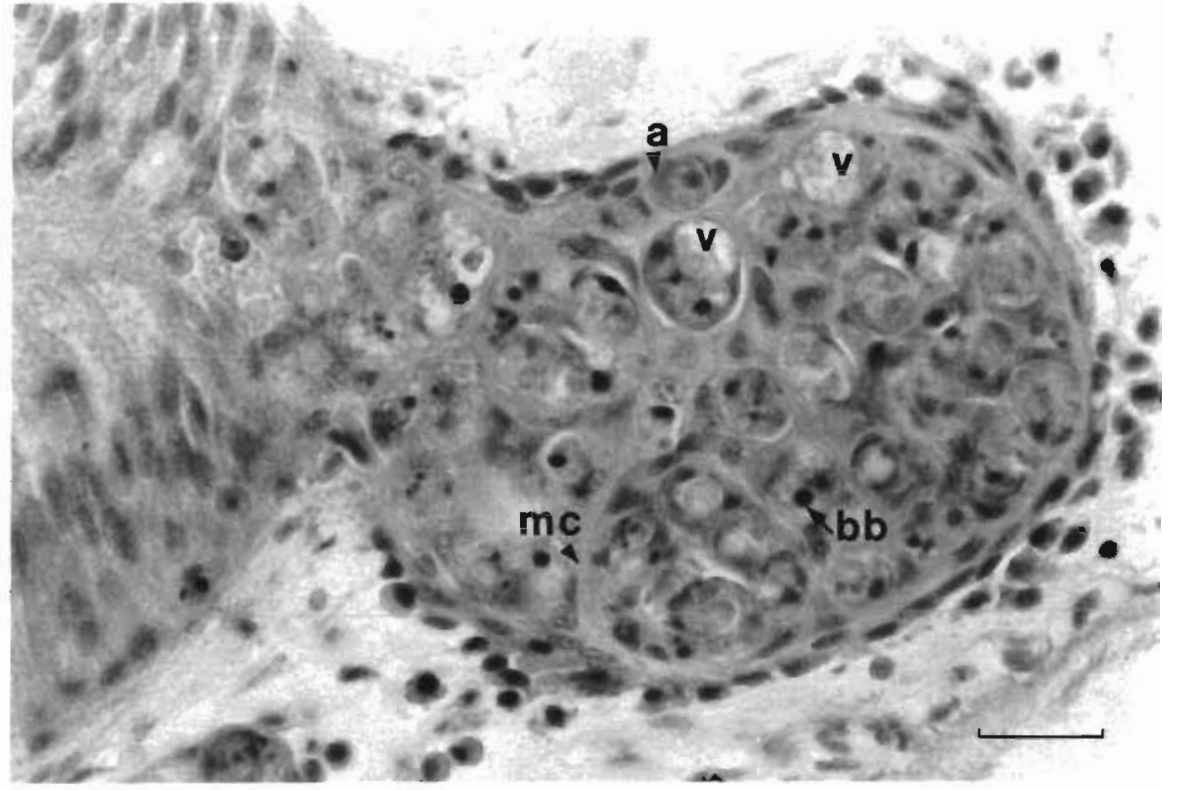

Fig. 3. Perkinsus karlssoni. Proliferation between the basement membrane and epithelial of the intestine: mc: mother cell $i_{i}$ a: aplanospores; v: vacuole; bb: basophilic body. $\left(\mathrm{H} \& \mathrm{E}_{\mathrm{i}}\right.$ bar $\left.=17.5 \mu \mathrm{m}\right)$ specimens was spherical measuring $2.16 \mu \mathrm{m}$. The large eccentric vacuole described for mature aplanospores in other Perkinsus species was rarely observed in this species ( $\mathrm{n}=7$ ), measuring $3.26 \pm 0.14$ (3.02 to 3.45$) \mu \mathrm{m}$ in diameter (Fig.3). Granules of the cytoplasm were basophilic and there was usually a dense basophilic body $(1.08 \mu \mathrm{m})$ adjacent to the nucleus.

Zoosporangia stages were spherical with a short discharge tube visible in larger specimens (Fig.4). In tissues incubated in fluid thioglycollate medium for $120 \mathrm{~h}$ the zoosporangia measured $113.44 \pm 23.11(80.0$ to 138.3$) \mu \mathrm{m}$. The discharge tube measured up to $10 \mu \mathrm{m}$ in length. The biflagellate zoospores released from the zoosporangia measured $5.76 \pm 1.63$ (3.24 to 7.56) $\mu \mathrm{m}$ in length and $3.15 \pm 0.07$ (2.16 to 4.32) $\mu \mathrm{m}$ in width (Fig. 5a). The nucleus measured $2.16 \mu \mathrm{m}$ in diameter and a vacuole measuring $3.24 \mu \mathrm{m}$ in diameter was also present. In addition, this stage had a dense cytoplasmic inclusion next to the vacuole measuring $1.08 \mu \mathrm{m}$ in diameter. Flagella were unequal in size (mean ratio $3.85: 1.0$; ratio range 3 to $4: 1$ ) and emerged laterally from the anterior half of the body (Fig. 5b). The anterior flagellum measured $14.85 \pm 1.71$ (11.9 to 17.3$) \mu \mathrm{m}$ in length; the trailing flagellum measured $3.86 \pm 0.75$ (2.7 to 5.4$) \mathrm{um}$ in length.

Hosts. Argopecten irradians (Lamarck); possibly present in all life-history stages, although not detectable in individuals less than $6 \mathrm{mo}$ old or 7 to $10 \mathrm{~mm}$ in length, using histology or thioglycollate culture.

Transmission. Direct.

Locality. Gulf of St. Lawrence and Atlantic Nova Scotia, Canada (bay scallop introduced solely for aquaculture). Also Rhode Island, Connecticut (Karlsson 1990) and bay scallops from Cape Cod, Massachusetts (pers. obs.).
Type locality. Tracadie Bay, Prince Edward Island, Canada.

Slides with hapantotypes are deposited in the Canadian Museum of Nature, Ottawa, Ontario, Canada, specimen Nos. CMN1990-0026 to 0028 and CMN19900031. Specimen numbers correspond to: \#0026 is a thick-section of Epon-Araldite-embedded biflagellate zoospores fixed in $2 \%$ gluteraldehyde buffered with ambient seawater and post-fixed in $1 \%$ osmium tetroxide and stained with Toluidine Blue; $\# 0027$ is a $5 \mu \mathrm{m}$ thick histological section of infected Argopecten irradians tissue, preserved in $1 \mathrm{G} 4 \mathrm{~F}$, embedded in paraffin wax and stained in Harris's modified haematoxylin and $0.5 \%$ alcoholic eosin $\mathrm{y}$; \#0028 is a preparation of

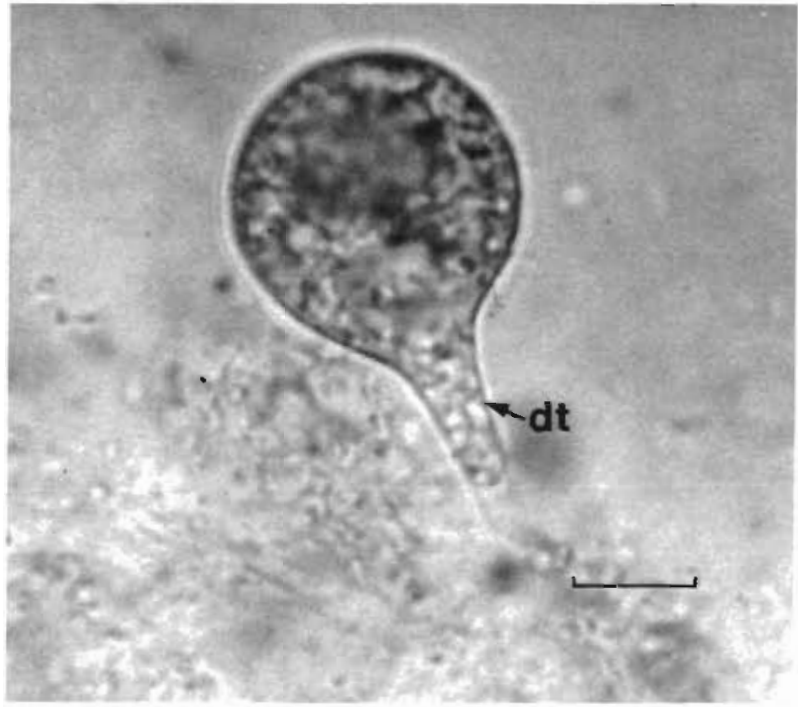

Fig. 4. Perkinsus karlssoni. Zoosporangium following transfer from thioglycollate culture to artificial seawater; dt: discharge tube. Live preparation viewed by phase contrast. (Bar $=27$ $\mu \mathrm{m})$ 
sporozoites, fixed in $2 \%$ gluteraldehyde/paraformaldehyde in ambient seawater, stained with Giemsa and sealed with Permount; \#0031 is a second thick-section of Epon-Araldite-embedded zoospores.

\section{Morphology of Perkinsus karlssoni in adult bay scallops}

Of the initial 46 adult bay scallops examined, 20 were found to contain 'swirl' lesions throughout the soft tissues (Fig. 2). The lesions were made up of hemocytes which encapsulated the protozoan parasite. The encapsulation responses were generally focal, although multiple lesions were found in the connective tissue of the digestive gland which had coalesced into abscesses. Many of the lesions contained varying amounts of ceroid, which rendered the contents of the encapsulation brown and masked detailed features of the parasite. Both the Gram stain and the Acid-Fast stain were

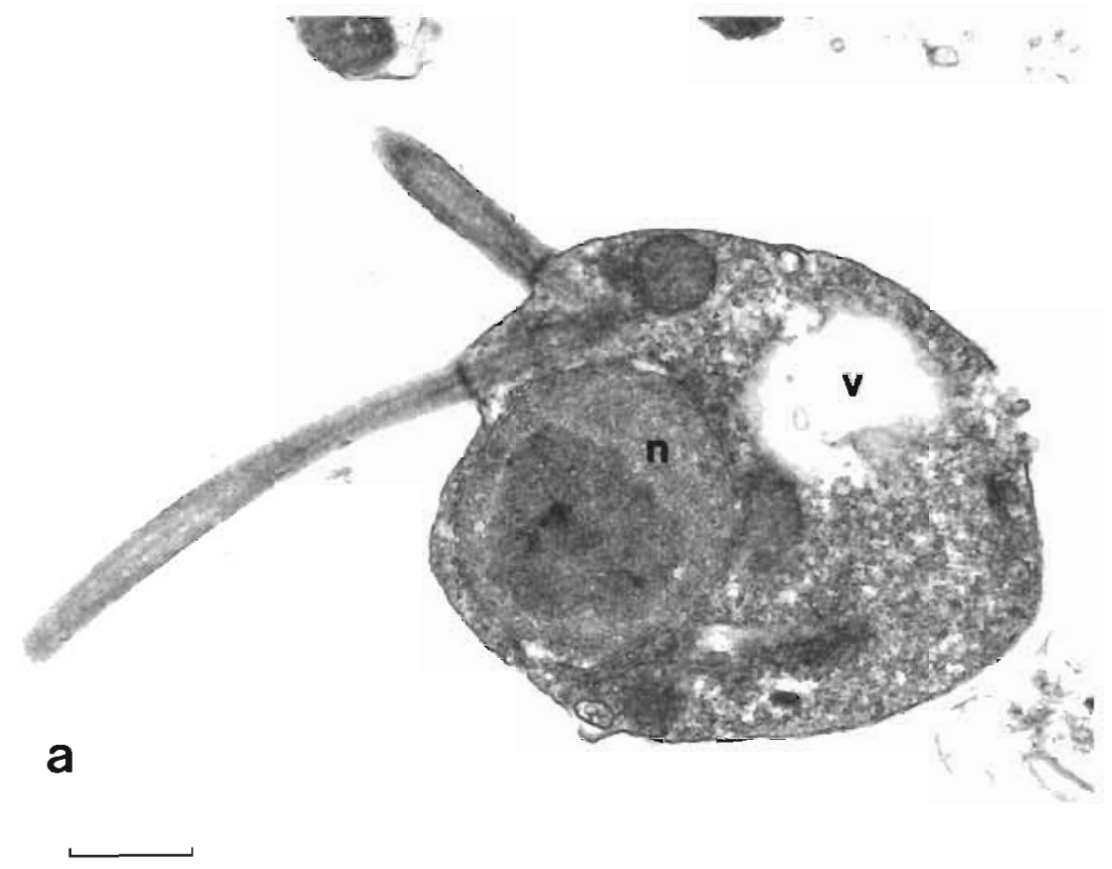

Fig. 5. Perkinsus karlssoni. (a) Biflagellate zoospore examined by electron microscopy. Note vacuole $(v)$ and large eccentric nucleus $(n)$. ( $\times 5200$; bar $=$ 1 um). (b) Enlarged section showing basal arrangement of the flagella. (x 18000)

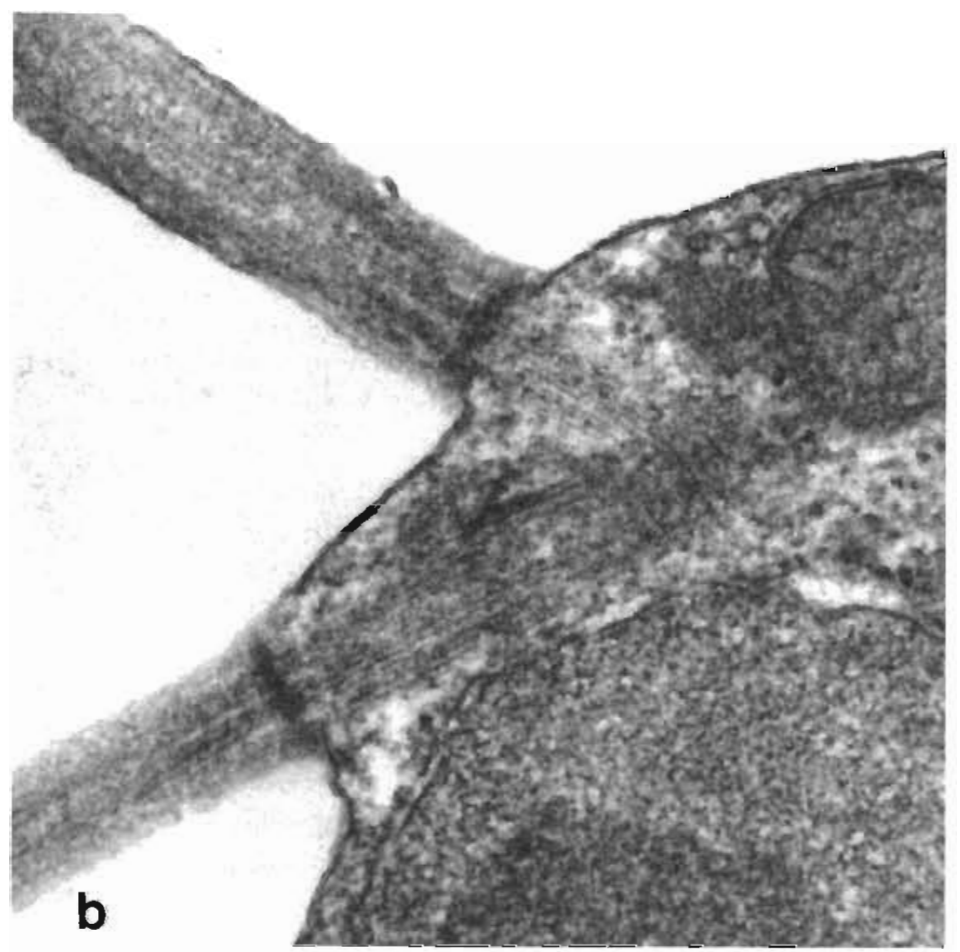


negative for bacterial association with the lesions. The MPAS stain, however, showed the contents of the parasite lesions to be weakly PAS positive.

Three of $20(15.0 \%)$ bay scallops collected from the Nova Scotia hatchery in May 1989 yielded blue-black spheres following incubation in Fluid Thioglycollate medium for $96 \mathrm{~h}$ and treatment with $50 \%$ Lugol's Iodine, while 4 of the 6 scallops $(66.7 \%)$ examined from the PEI hatchery ca 1 mo later were Lugol-positive. Several of the spheres demonstrated short protrusions that closely resembled those of the discharge tubes described for zoosporangia of other species of Perkinsus (Ray 1954, Perkins \& Menzel 1966, 1967, Azevedo 1989). Only isolated zoosporangia or clumps of up to 36 were observed in thioglycollate-cultured bay scallop tissues. Tissues placed in seawater, post-thoglycollate culture, and maintained at room temperature $\left(22^{\circ} \mathrm{C}\right)$ developed aggregations of zoosporangia of up to several hundred (Fig. 3). This is believed to be continued production of zoosporangia, post-thioglycollate culture, rather than a secondary proliferation of prezoosporangia.

\section{Development of parasite in spat generation}

In bay scallops grown in warm water, the appearance of the parasite occurred 3 mo earlier than observed in bay scallops grown in the field. The parasite first appears among the epithelial cells as well as between the epithelial cells and basement membrane of the intestine running through the gonads (Fig. 4). It undergoes multiple schizogony in this location and then appears to spread, via the circulatory system, throughout the body (gills, kidney, digestive gland and muscle).

The parasite was not detectable using routine histology or thioglycollate culture in the spat generation ( 5 mo old), prior to their transferral from the Nova Scotia hatchery and PEI grow-out site to the Atlantic Veterinary College. Once transferred the parasites emerged within 4 wk using thioglycollate culture and 6 wk by histological examination. Histologically the parasites were less encapsulated than those found earlier in broodsock bay scallops and their initial appearance was limited to around the portion of the intestine running through the gonads, rather than predominantly throughout the connective tissue of the digestive gland. In several sections the parasites distended the basement membrane into the surrounding connective tissue (Fig. 3).

\section{Observations of zoosporangia and biflagellate zoospores in artificial seawater}

Following removal of the bay scallop tissues from thioglycollate culture medium and immersion in artifi- cial seawater inoculated with nystatin, the biflagellate zoospores took from 7 to $21 \mathrm{~d}$ to appear (at 18 to $22^{\circ} \mathrm{C}$ ). They maintained close contact with the bottom of the dish and demonstrated weak adhesion. This stage was active for at least $6 \mathrm{wk}$ in artificial seawater kept at room temperature.

At $4{ }^{\circ} \mathrm{C}$, the zoospores lost their motility almost immediately but regained it after 5 to $10 \mathrm{~min}$ at room temperature. They retained this ability for up to $9 \mathrm{wk}$ storage at $4^{\circ} \mathrm{C}$ in artificial seawater.

The biflagellate zoospores exhibited low tolerance to osmolarity changes. The artificial seawater cultures were kept at a salinity of $2.8 \%$, to reflect that of fieldgrowing conditions. When placed in full strength salinity $(3.3 \%)$ or reduced salinity $(0.5$ and $1.5 \%)$, all biflagellates rounded up and ceased motion within 10 to $15 \mathrm{~min}$. They did not resume motility when returned to $2.8 \%$ salinity.

Development of the parasite in thioglycollate culture was also retarded after infected bay scallops had been held at water temperatures of 5 to $10^{\circ} \mathrm{C}$ for over 1 wk. In these cases the parasite could only be detected by using histology.

\section{Development of parasite under ambient field conditions}

In November 1989, 100 bay scallops, 100 blue mussels and 100 American oysters were collected from Tracadie Bay, PEI. Samples of 100 bay scallops, 100 blue mussels and 100 European oysters were also collected from Corkums Bay, Nova Scotia (Fig. 1).

In the bay scallops from both Tracadie Bay and Corkums Bay, all histological sections revealed massive haemocyte infiltration of the digestive gland, mantle, gills and gonads. Only 6 individuals from Corkums Bay, however, demonstrated clear evidence of the parasite in tissue sections. Forty-eight \% of the thioglycollate cultures from Corkums Bay bay scallops and $95 \%$ of thioglycollate cultures from Tracadie Bay bay scallops were positive.

The American oysters from Tracadie Bay showed varying degrees of tissue infiltration by granulocytes, as well as extensive ceroid infiltration. However, there was no histological evidence of the same apicomplexan parasite observed in bay scallops. Neither the European oysters nor the blue mussels showed any abnormal histopathology and Perkinsus karlssoni was not observed. Nearly all the thioglycollate cultures of tissues from these specimens revealed varying degrees of blue-black staining 'bodies'. Although these resembled some found in bay scallop tissue, none had the distinct spheres associated with Perkinsus species, which were seen solely in bay scallop tissue. In addition, none of other Iugol-positive tissues developed the biflagellate 
stage when placed in artificial seawater and it is believed that the irregular shaped solid-staining 'bodies are staining artifacts (pers. comm., Bower, S. M., Pacific Biological Station, D. F. O., Nanaimo, British Columbia, Canada V9R 5K6).

\section{DISCUSSION}

\section{Morphology of Perkinsus karlssoni in adult bay scallops}

The initial observation of this parasite within the post-spawning bay scallops indicated a highly localized tissue response. This did not appear to be directly responsible for the post-spawning mortality, which is characteristic for bay scallops (Gutsell 1930). Parasites were encapsulated by one to several layers of hemocytes and some appeared to have been phagocytosed within the encapsulation 'swirl' (Fig.6). There was also extensive ceroid deposition in and around the encapsulation site which is characteristic of both Perkinsus infections (Mackin 1951, Stein \& Mackin 1955) and those of other parasites (Cheng \& Burton 1965, Cheng 1981). The parasites themselves were difficult to distinguish from host tissue within such marked tissue encapsulation and their viability was questionable. In certain sites, such as the stomach and intestinal epithelium, however, the parasites were less heavily encapsulated and individual cells were more easily distinguished. In areas of extensive parasite aggregation individual encapsulation responses coalesced into tissue abscesses. The tissue responses found in the postspawning broodstock were similar to those found subsequently in the spat generation, but the latter demonstrated less extensive hemocyte encapsulation (Fig. 2).
These tissue responses were similar to those described for Perkinsus-like organisms in 12 of 16 bivalve species from Chesapeake Bay (Andrews 1955), where the parasites were found to be clustered and encapsulated. The additional observation that, although almost all individuals appeared to be infected, intensity of infection was mainly 'light', concurs with observations of infections of bay scallops grown under field conditions $(50$ to $95 \%$ infection, based on thioglycollate culture, and 0 to $10 \%$ based on histological examinations). Relatively few individuals collected from natural grow-out sites were found to have aggregations of over 10 parasites per cyst, compared with the massive aggregations (Fig. 3) found in the experimental individuals grown under consistently warm water conditions. The size range of 3 to $10 \mu \mathrm{m}$ given for vacuolated trophozoites of $P$. marinus (Perkins 1976) is similar to that of P. karlssoni (4.3 to $7.6 \mu \mathrm{m}$ ) (Table 1). None of the smaller (2 to $4 \mu \mathrm{m}$ ), non-vacuolated forms described for $P$. marinus were observed in the bay scallop samples examined.

With respect to thioglycollate development described for Perkinsus marinus (Ray 1966), P. olseni (Lester \& Davis 1981) and P. atlanticus (Azevedo 1989), no massive spore development was demonstrated in the thioglycollate medium by $P$. karlssoni. Although this may reflect a difference in the biology of this parasite, it should be noted that all the other species described have been studied in hosts growing in their natural enviromment. All bay scallops growing on the east coast of Canada are derived from broodstock introduced in 1979/80 and all subsequent generations have been spawned under artificially controlled temperature regimes in shellfish hatcheries. It is possible, therefore, that growth and development of the bay scallop Per-

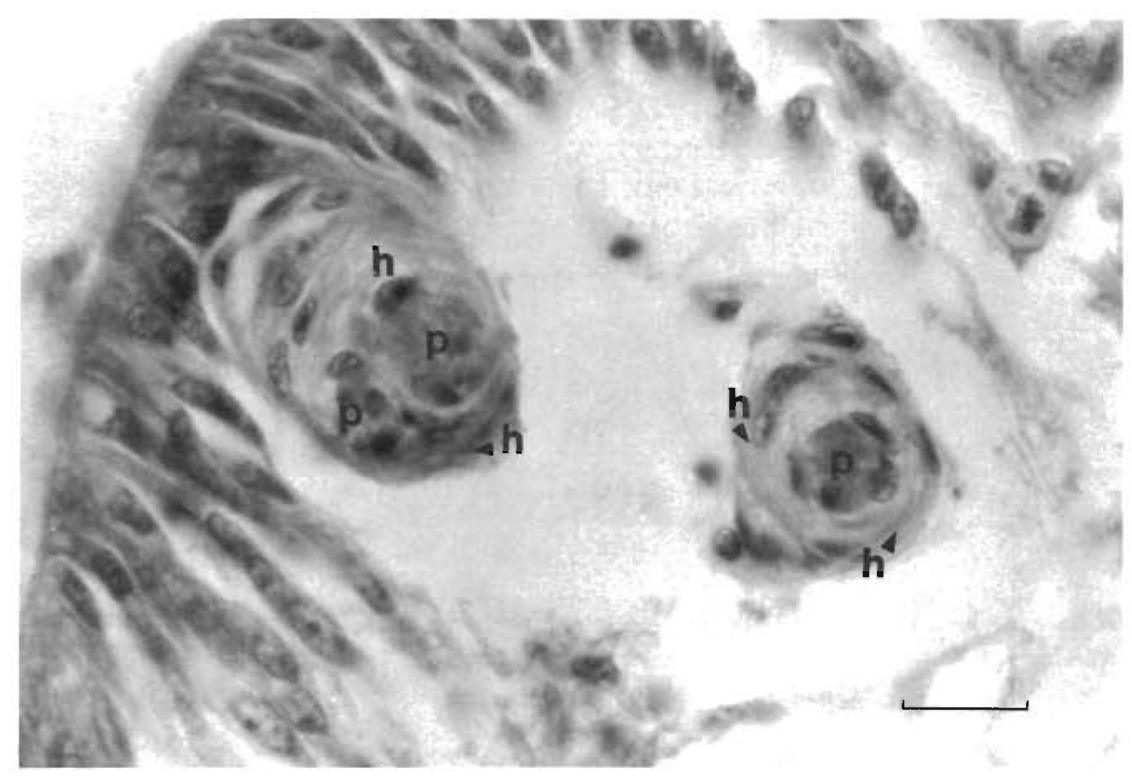

Fig. 6. Perkinsus karlssoni. Haemocyte (h) 'swirl' encapsulation (p) in the digestive gland of post-spawned, moribund bay scallops examined by light microscopy using $\mathrm{H} \& \mathrm{E}$. (Bar = $5 \mu \mathrm{m})$ 
kinsus parasite may be affected by this semi-natural system. Development of the same parasite in uncultivated bay scallops growing south of the Gulf of Maine has yet to be studied.

One difference between the appearance of this species and previously described perkinsiids was the apparent rarity of the large eccentric vacuole in the aplanospore stage. Azevedo (1989) clearly described the development of the vacuole and associated vaculoplast for Perkinsus atlanticus as the aplanospore matured. A similar development of this cytoplasmic feature was described for $P$. marinus by Perkins (1976) and all stages of development of trophozoites from $P$. olseni were observed to have vacuoles (Lester \& Davis 1981). Lester \& Davis (1981) noted, however, that dead nuvliter ceils, coliected from smears, appeared to lose their vacuoles. The temperature-dependent proliferation of the aplanospore stages in bay scallops and the physiological correlation between the artificially short high temperature period for spawning the broodstock under hatchery conditions may have contributed to the lack of vacuole development in the tissue stages observed. Since it is equally possible, however, that this species does not develop a distinct vacuole or vaculoplast, the morphology of the aplanospoore stage in broodstock bay scallops was compared with that in the spat generation which was held for 6 mo at 22 to $25^{\circ} \mathrm{C}$. No significant difference in the presence of the vacuole was observed. A densely basophilic body was a consistent feature, however, in both the tissue and biflagellate stages (Figs. $3 \& 5$ a). This inclusion strongly resembled the electron-dense vaculoplasts described for other species of Perkinsus (Perkins 1976, Lester \& Davis 1981, Azevedo 1989).

A similar parasite in bay scallops was presented by Karlsson (1990), who described a eukaryote parasite from the connective tissue of the gills, digestive gland and gonads of bay scallops from Rhode Island, USA. A Perkinsus-like organism was also reported from 11 out of 11 bay scallops collected from Florida (Ray \& Chandler 1955). This record was based entirely on results from thioglycollate culture and no morphological descriptions of the spores produced were provided which could be used for comparison with the parasite herein described.

Based on the development of Lugol-positive zoosporangia in thioglycollate culture and the similarities in morphology of all stages of development currently identified (Table 1), compared with other thioglycollate sensitive Perkinsus species, we believe that the apicomplexan found in bay scallops is a new species belonging to the genus Perkinsus. Since the parasite found by Karlsson (1990) in bay scallops from Rhode Island is histologically identical to that found in bay scallops in Canada, we also believe that they are the same species (pers. comm., Karlsson, J. D., Coastal Fisheries Laboratory, 1231 Succotash Road, Wakefield Rhode Island, 02879, USA). To date, this parasite appears to be specific to bay scallops; however, crosstransmissability studies are ongoing.

\section{Development of parasite in spat generation}

One marked difference between infections in broodstock and those observed in the spat generation grown under artificial conditions was the number of parasites found at specific tissue sites. In broodstock bay scallops the numbers of aplanospores rarely exceeded 10 to 12 per parasite aggregation. In direct contrast, hundreds of individual parasites were frequently observed within single aggregations in the individuals grown at 22 to $25^{\circ} \mathrm{C}$. Proliferation of the parasite appears, therefore, to be positively correlated to temperature. Statistical correlation coefficients could not be accurately determined from histological observations. With respect to development of the vacuole, extended development of the parasite within healthy specimens did not enhance its appearance. Despite this distinct difference in morphology of the trophozoite stage compared to other species of Perkinsus, the appearance and proliferation of the bay scallop parasite was identical to that described for $P$. marinus in Crassostrea virginica. $P$. karlssoni first appeared inbetween the epithelial cells of the proximal portion of the intestine which loops through the gonads (Fig. 2). The parasites appear to

Table 1. Comparative measurements of previously described Perkinsus species and P. karlssoni

\begin{tabular}{|c|c|c|c|c|c|c|}
\hline Species & Host & Aplanospore & Mother cell & $\begin{array}{c}\text { No. of } \\
\text { daughter cells }\end{array}$ & Zoosporangia & Zoospores \\
\hline P. marinus & Crassostrea virginica & $3-10 \mathrm{~m}$ & $15-40 \mathrm{~m}$ & $30-50$ & $40-300 \mathrm{~m}$ & $2-5 \mathrm{~m}$ \\
\hline P. atlanticus ${ }^{b}$ & Ruditapes decussatus & $30-40 \mathrm{~m}$ & $30-40 \mathrm{~m}$ & 100 s & na & $4.5 \times 2.9 \mathrm{~m}$ \\
\hline P. olsenic & Haliotis ruber & $14-18 \mathrm{~m}$ & $19 \mathrm{~m}$ & na & $56-94 \mathrm{~m}$ & na \\
\hline P. karlssoni n. sp. & Argopecten irradians & $4.3-7.6 \mathrm{~m}$ & $13-73 \mathrm{~m}$ & $2-32$ & $80-138 m$ & $3.2 \times 5.8 \mathrm{~m}$ \\
\hline
\end{tabular}


aggregate either between the columnar cells themselves or, more commonly, between these cells and the basement membrane. Large groups of parasites frequently distended the basement membrane into the surrounding connective tissue (Fig. 3). They subsequently appeared systemically throughout the soft tissues. The predominant sites of lodgement were in the connective tissues around the digestive diverticula, indicating circulation via phagocytic haemocytes. This pattern of spread is identical to that described by Perkins (1976) for P. marinus.

Growth rates of bay scallops in our warm water facilities were similar to those under ambient field conditions. The assumption that growth would be faster under warm water conditions was, therefore, not supported. It was not possible to determine from this investigation whether this was due to the greater intensity of parasite infection in the experimental system compared with that in the field, or a reflection of the batch feeding method employed in the experimental rearing system compared with the relatively constant natural food supply.

One spat sample used for the warm water holding experiment was collected directly from the hatchery and had not been exposed to field conditions or any other bivalve species (the second source of spat had been put out in Chinese lantern nets into a grow-out site for ca $4 \mathrm{wk}$ prior to collection). Since broodstock are only briefly held in the same tanks as their spawning products (to reduce the chances of self-fertilization) (Sastry 1970, Castanga 1975, Morrison \& Shum 1982, 1983), the infective stage of the parasite was most likely transmitted directly with the reproductive products in order to infect the spat generation. There is no evidence for a transport host, such as suggested for Perkinsus marinus (White et al. 1987). Infection of the spat generation could not be detected using thioglycollate culture or histology until they reached 7 to $10 \mathrm{~mm}$ in length (ca 6 mo of age). When the spat/juvenile bay scallops were transferred to warm water, however, the parasite appeared after $3 \mathrm{wk}$ using thioglycollate culture and $6 \mathrm{wk}$ using histology. The cryptic nature of the early development stages is well-described for $P$. marinus in American oysters, where the spat are refractile to $P$. marinus until 3 to $4 \mathrm{mo}$ old and death rates are low during the first year of life (Ray 1954). In descriptions of the development of both $P$. olseni (Lester \& Davis 1981) and P. atlanticus (Azevedo 1989) and other undescribed Perkinsus species (Ray \& Chandler 1955. Goggin \& Lester 1987), the size of the hosts examined is not given, but are assumed to have been mature specimens.

One interesting observation from the spat collected from both sources was that there was no difference in level of infection between the two, despite a marked difference in their sizes. Spat collected directly from the Nova Scotian hatchery were consistently smaller than those collected from the grow-out site. This indicates development of the parasite is less dependent on hostsize than environmental temperature. Additionally, the spat collected from the grow-out site did not contain more parasite infections than those collected directly from the hatchery. This reinforces the supposition that infection by Perkinsus karlssoni occurs during spawning and not following transferral to coastal grow-out sites.

Although spawning has not been cited as an important factor in transmission of Perkinsus marinus, extensive field observations suggest that the density and proximity of dead and dying oysters are important for transmission (Andrews 1965). Since post-spawning bay scallops are often moribund, this may be an important factor in the transmission of the parasite, especially under the stressful conditions of hatchery-induced spawning following low temperature overwintering (Castagna 1975). In addition, the limited volume and exchange-rate of the warm water in which the spat are kept for the first 2 mo of life may further enhance transmission. The possibility of enhancing parasite transmission and accumulation in intensive aquaculture has been suggested previously (Morrison \& Shum 1983, Bower \& Fiqueras 1989, Leibovitz 1989).

\section{Observations of spore and biflagellate stages in artificial seawater}

Following transferral of positive tissues from thioglycollate culture to artificial seawater inoculated with nystatin, continued development of the zoosporangia stage was observed for up to $2 \mathrm{wk}$. After this initial period in seawater thousands of highly active biflagellate zoospores appeared. These resembled the zoospores of Perkinsus marinus except that the flagellar ratio was higher $(3.85: 1)$ than that of $P$. marinus (ca $2: 1)$ and there was a slight difference in size range ( $P$. marinus 3 to $10 \mu \mathrm{m}$ in length; $P$. karlssoni 3.76 to 7.84 $\mu \mathrm{m}$ in length). There was no detailed description of the morphology of this stage for $P$. olseni (Lester \& Davis 1981). However, that given by Azevedo (1989) for $P$ atlanticus closely resembles that of $P$. karlssoni with respect to size, but differs markedly with respect to flagellar ratio $(1.2: 1)$ and flagellar morphology. The posterior flagellum of $P$. atlanticus is divided into 2 distinct portions, which does not occur with the flagellum of $P$. karlssoni. The anterior and adjacent positioning of the flagella of both species, however, appears similar.

Temperature and salinity tolerances of the zoospore stages of the other Perkinsus species have not been 
tested, although epidemiological observations of $P$. marinus pathology indicate a strong sensitivity to temperature and, to a lesser degree, salinity (Ray 1954). There have been no known cases of oyster mortalities due to $P$. marinus north of Chesapeake Bay, and infected individuals moved into Delaware Bay have never produced the persistent disease outbreaks found further south (Ray 1954). Since the bay scallop parasite appears capable of surviving for at least 3 mo at $5^{\circ} \mathrm{C}$, when the broodstock are held overwinter prior to conditioning for spawning, and the zoospore stage can survive for up to $9 \mathrm{wk}$ at $4{ }^{\circ} \mathrm{C}$ (although their viability following such treatment has not yet been investigated), this reinforces the morphological observation that the bay scallop parasite is not $P$. marinus, which is believed to develop oniy when water temperatures exceed $20^{\circ} \mathrm{C}$. In addition, the observation of exceptionally heavy infections in individuals which were not reconditioned for spawning (exposed to warmer water) indicates that the tissue stages of $P$. karlssoni may be capable of development at lower water temperatures. Unfortunately there are no similar epidemiological studies for $P$. olseni or $P$, atlanticus.

\section{Development of parasite under ambient field conditions}

Using histological analysis, field collections of bay scallops yielded a much lower prevalence of parasite infection ( 0 to $10 \%$ ) compared to those from the scallops grown experimentally (31 to $45 \%$ ). However, equally high thioglycollate culture results (60 to $100 \%$ ) were obtained from both groups of scallops. An interesting histological observation of all the bay scallops examined was extensive haemocyte infiltration of the connective tissues. This infiltration was so heavy that there were marked vascular occlusions, despite the absence of clear evidence of the parasite. This tissue response, especially with respect to the focal infiltration lesions, is similar to that described for early infections of Perkinsus marinus in Crassostrea virginica (Perkins 1976).

Histological examination of other bivalve species grown adjacent to infected bay scallops showed no evidence of transmission of the parasite. There was systemic granulocytic infiltration in $100 \%$ of the Crassostrea virginica from Tracadie Bay, PEI. However, this haemocyte activity could not be distinguished from that which occurs in almost all American oysters growing in the Gulf of St. Lawrence and which is attributed to Malpeque Disease (Needler \& Logie 1947, Li 1976). No similar haemocyte infiltration was found in either the blue mussels or the European oysters. The lack of evidence for inter-species transmission supports the theory of Ray (1954) that Perkinsus species are host- specific, and the speculation of Goggin \& Lester (1987) that more than one species were responsible for the positive thioglycollate results of many different bivalve species from the Great Barrier Reef. Subsequent work by Goggin et al. (1989) has demonstrated, however, that Perkinsus cross-transmission may be possible for certain bivalve species.

Thioglycollate culture of the same bivalve specimens which were examined histologically yielded Lugolpositive 'bodies'. These Lugol-positive 'bodies' were irregular in shape and solid-staining, in marked contrast to those found solely in bay scallops, which were spherical and showed varying degrees of transluscency. In addition to the difference in appearance of the 2 types of Lugol-positive bodies, those from the blue mussels, American oysters and European oysters failed to produce biflagellates when placed in treated artificial seawater. Test samples of blue mussels and American oysters from New Brunswick, which has no bay scallop aquaculture, yielded similar blue-black staining inclusions following thioglycollate incubation. These 'bodies' are, therefore, believed to be artifacts produced by Lugol-lodine precipitates or ceroid material within the tissues.

The pathogenicity of Perkinsus karlssoni has yet to be clearly established since proliferation takes place throughout the tissues of the bay scallop at the same time as gonadal maturation. Histological observations suggest that the pathogenicity of the parasite may be enhanced when the bay scallops are physiologically stressed by spawning. The actual significance of parasite load, post-spawning trauma and hatchery manipulation, however, is difficult to distinguish and requires further investigation.

Acknowledgements. We thank Mr A. Eade and Ms C. Paton for their technical assistance; Department of Fisheries and Oceans (Scotia-Fundy) for the case-history information on the introduction of the bay scallop to Canada; Dr M. M. Helm, Mr $\mathrm{J}$. Townson and Mr R. Townsend for valuable advice as well as the bivalves used for this study; and Mr M. Mallet and Mr J. Jenkins, Department of Fisheries and Oceans (Gulf) and Mr I Judson, Department of Fisheries and Aquaculture Prince Edward Island, who coordinated funding and support. We are also grateful to Mr R. Drinnan, Mr C. A. Farley, Mr J. D. Karlsson, Dr C. Azevedo, Dr S. M. Bower and Dr E. Burresson for their valuable comments on the identification and potential implications of the bay scallop parasite. In addition, Dr Bower and $\mathrm{Mr}$ Farley provided valuable comments on the preliminary draft of this manuscript. Funding was provided by Department of Fisheries and Oceans (Gulf); an ACOA and PEI Mussel Growers Development Grant to the Atlantic Veterinary College and an NRC IRAP-H.

\section{LITERATURE CITED}

Andrews, J. D. (1955). Notes on fungus parasites of bivalve mollusks in Chesapeake Bay. Proc. natn. Shellfish. Ass. 45: $157-163$ 
Andrews, J. D. (1965). Infection experiments in nature with Dermocystidium marinum in Chesapeake Bay. Chesapeake Sci. 6: 60-67

Azevedo, C. (1989). Fine structure of Perkinsus atlanticus n. sp. (Apicomplexa, Perkinsea) parasite of the clam Ruditapes decussatus from Portugal. J. Parasitol. 75 (4) $627-635$

Bower, S. M., Figueras, A. J. (1989). Diseases of mussels World Aquacult. Rev. 20 (4): 89-93

Clarke, A. H., Jr (1965). The scallop super species Argopecten irradians (Lamarck). Malacalogia 2 (2): 161-188

Castagna, M. (1975). Culture of the bay scallop Argopecten irradians, in Virginia. Mar. Fish. Rev. 37 (1): 19-24

Cheng, T.C. (1981). Bivalves. In: Ratcliffe, N. A., Rowley, A. F. (eds.) Invertebrate blood cells, Vol.1. Academic Press New York, p. 233-300

Cheng, T. C., Burton, R. W. (1965). Relationships between Bucephalus sp. and Crassostrea virginica: histopathology and sites of infection. Chesapeake Sci. 6: 3-16

Farley, C. A. (1977). Neoplasms in estuarine mollusks and approaches to ascertain causes. In: Kraybill, H. F., Dawe, C. J., Harshbarger, J. C., Tardiff, R. G. (eds.) Aquatic pollutants and biologic effects with emphasis on neoplasia. Ann. N.Y. Acad. Sci., p. 225-232

Goggin, C. L., Lester, R. J. G. (1987). Occurrence of Perkinsus species (Protozoa, Apicomplexa) in bivalves from the Great Barrier Reef. Dis. aquat. Org. 3: 113-117

Goggin, C. L., Sewell, K. B., Lester, R. J. G. (1989). Crossinfection experiments with Australian Perkinsus species. Dis. aquat. Org. $7(1): 55-59$

Gutsell, J. S. (1930). Natural history of the bay scallop. U.S. Bur. Fish. Bull. 46: 569-632

Howard, D. W., Smith, C. S. (1983). Histological techniques for marine bivalve mollusks. NOAA Tech. Memo. NMFS-F/ NEC-25, $95 \mathrm{p}$

Karlsson, J. D. (1990). Parasites of the bay scallop, Argopecten irradians Lamarck. In: Shumway, S. E. (ed.) International compendium of scallop biology and culture. World Aquaculture Society and National Shellfisheries Association, p. $180-190$

Leibovitz, L. (1989). Chlamydiosis: a newly reported serious disease of larval and postmetamorphic bay scallops, Argopecten irradians (Lamarck). J. Fish. Dis. 12: 125-136

Leibovitz, L., Schott, E. F., Karney, R. C. (1984a). Diseases of wild, captive and cultured scallops. In: Capuzzo, J.M. (ed.) Bay scallop fishing: problems and management. Woods Hole Oceanographic Institution. Technical Report WHOI$84-38$, p. $8-9$

Leibovitz, L., Schott, E. F., Kamey, R. C. (1984b). Diseases of wild, captive and cultured scallops. J. World Maricult. Soc. 15: $269-283$

Responsible Subject Editor: A. K. Sparks, Seattle, Washington, USA
Lester, R. J. G., Davis, G. H. G. (1981). A new Perkinsus species (Apicomplexa, Perkinsea) from the abalone Haliotis ruber. J. Invert. Pathol. 37-181-187

Li, M. F. (1976). A microparasite, the possible causative agent of Malpeque disease of oysters. Proc. Can. Fedn. biol. Socs. 19: 158

Mackin, J. G. (1951). Histopathology of infection of Crassostrea virginica (Gmelin) by Dermocystidium marinum Mackin, Owen and Collier Bull. mar Sci. Gulf Caribb. 1. $72-87$

Mackin, J. G., Owen, H. M., Collier, A. (1950). Preliminary note on the occurrence of a new protistan parasite, Dermocystidium marinum $\mathrm{n}$. $\mathrm{sp}$. in Crassostrea virginica (Gmelin). Science 111: 328-329

Morrison, C., Shum, G. (1982). Chalmydia-like organisms in the digestive diverticula of the bay scallop, Argopecten irradians (Lmk). J. Fish. Dis. 5: 173-184

Morrison, C., Shum, G. (1983). Rickettsias in the kidney of the bay scallop, Argopecten irradians (Lamarck). J. Fish. Dis. 6: $537-541$

Needler, A. W. H., Logie, R. R. (1947). Serious mortalities in Prince Edward Island oysters caused by a contagious disease. Trans. R. Soc. Can. 41: (Ser. 3, Sect. 5): 73-89

Perkins, F. O. (1976). Dermocystidium marinum infection in oysters. Mar. Fish. Rev. 38 (10): 19-21

Perkins, F. O., Menzel, R. W. (1966). Morphological and cultural studies, of a motile stage in the life-cycle of Dermocystidium marinum. Proc. natn. Shellfish Ass. 56: 23-30

Perkins, F. O., Menzel, R. W. (1967). Ultrastructure of sporulation in the oyster pathogen Dermocystidium marinum. J. Invert. Pathol. 9: 205-229

Ray, S. M. (1954). Biological studies of Dermocystidium marinum. Rice Inst. Pamph. No. 41 (Spec. Issue): 1-114

Ray, S. M. (1966). A review of the culture method for detecting Dermocystidium marinum, with suggested modifications and precautions. Proc, natn. Shellfish. Ass. 54: 55-69

Ray, S. M., Chandler, A. C. (1955). Dermocystidium marinum, a parasite of oysters. Expl. Parasit. 4: 172-200

Sastry, A. N. (1970). Environmental regulation of oocyte growth in the bay scallop Aequipecten irradians Lamarck Biol. Bull. mar. biol. Lab., Woods Hole 138: 56-65

Stein, J. E., Mackin, J. G. (1955). A study of the nature of pigment cells of oysters and the relation of their numbers to the fungus disease caused by Dermocystidium marinum. Tex. J. Sci. 7: 422-429

White, M. E., Powell, E. N., Ray, S. M., Wilson, E. A. (1987). Host-to-host transmission of Perkinsus marinus in oyster (Crassostrea virginica) populations by the ectoparasitic snail Boonea impressa (Pyramidellidae). J. Shell. Res. 6 $1-5$

Manuscript first received: September 6, 1990

Revised version accepted: January 3, 1991 